\title{
RESULTS OF INVESTIGATION IN CORROSION PROCESSES IN GASIFYER GASIFYING FUELS CONTAINING STRAW AND LIGNIN
}

\author{
Anna Holubenko, Nataliya Tsyvenkova, Inna Nezdvetskaya, Oleg Pluzhnikov \\ Zhytomyr National Agroecological University, Ukraine \\ anikagogobl@gmail.com, nataliyatsyvenkova@gmail.com, inezd@ukr.net, torrent_17@ukr.net
}

\begin{abstract}
To gasify low quality biofuels it is proposed to use a downdraft gasifier with productivity by gas 60$68 \mathrm{~m}^{3} \cdot \mathrm{h}^{-1}$. The research was made for fuel mixtures of chopped straw and hydrolyzed lignin with variable acidity. A multifactor experiment was made to estimate the influence of acidity and the moisture content of fuel mixture as well as temperature in an active zone of the gasification chamber on corrosion rate of an experimental specimen made of $15 \mathrm{Cr} 21$ N5T. Similar experiments were made for specimens made of S32109, A57036 and $\mathrm{Ni70Cr} 27 \mathrm{Al}$. It was found that the moisture content influences corrosion more than acidity. Minimal corrosion rate was observed for fuel mixture with the moisture content $25 \%$ and pH6. When raising temperature in the gasification chamber active zone from 600 to $1000{ }^{\circ} \mathrm{C}$, the corrosion rate rises by $8 \%$ for the mixture with the moisture content $25 \%$ and pH6 and by $17 \%$ for the mixture with the moisture content $45 \%$ and pH5. Within the interval $900-1000^{\circ} \mathrm{C}$ the highest quality producer gas was received having the calorific value of $9.6 \mathrm{MJ} \cdot \mathrm{Nm}^{-3}$ with output of $2.7 \mathrm{~m}^{3} \cdot \mathrm{kg}^{-1}$. It is confirmed that between $900-1000{ }^{\circ} \mathrm{C}$ chloride and sulphide corrosion is significant for all types of materials. Raising the nickel content in alloy is lowering its corrosion resistance, which is confirmed with the specimen made of Ni70Cr27Al. Adding superheated steam to blowing gases is intensifying all corrosion processes. The received results of the corrosion processes could form a base of studying and computing other types of thermo-chemical conversion of low quality biofuels with similar chemical composition.
\end{abstract}

Keywords: gasification, chloride and sulphide corrosion, hydrolyzed lignin, acidity.

\section{Introduction}

Significant greenhouse gases emission when burning fossil fuels persuades to convert to renewable energy sources [1]. According to Eurostat the share of energy from renewable sources in gross final consumption of energy in the EU 28 countries increased from $8.5 \%$ in 2004 to $16.7 \%$ in 2015 [2]. This is evidence of a progress towards the Europe 2020 target of $20 \%$. With more than half $(53.9 \%)$ of energy from renewable sources in its gross final consumption of energy, Sweden had in 2015 by far the highest share, ahead of Finland (39.3\%), Latvia (37.6\%), Austria $(33.0 \%)$ and Denmark $(30.8 \%)$ [2]. Biomass gave almost two thirds of renewable-based energy $(71.3 \%)$. The 2030 European strategy for low carbon development calls for $40 \%$ of energy to be produced from renewable sources [1]. As part of that, a national task of Ukraine is "To increase the amount of energy from the renewable sources in the national energetic balance by means of introduction new capacity of the mechanisms, which produce energy from the renewable sources".

Ukraine possesses significant amount of renewable biofuels, such as straw (70 million ton/year), tree peeling residues - bark, branches, chips (around 20 ton $\cdot \mathrm{ha}^{-1}$ of lumbering) and hydrolyzation industry residues - hydrolyzed lignin (5 million ton $\cdot$ year $^{-1}$ ) [3]. However, their energy conversion is complicated due to high content of $\mathrm{K}, \mathrm{Na}, \mathrm{S}, \mathrm{Cl}, \mathrm{P}, \mathrm{Ca}, \mathrm{Mg}, \mathrm{Fe}, \mathrm{Si}$ in them and its predisposition (especially straw) to slagging [4-6]. Complications of energy conversion of low quality biofuels are conditioned by complexity of their origin, polyvariancy of their structural connections and interconnections between them. The presented low quality fuels, especially hydrolyzed lignin, are able to change their properties irreversibly under thermal and chemical influence [7].

According to $[4 ; 8]$, one of the high efficiency methods of low quality biofuel energy conversion is gasification. Comparing gasification with direct burning of these fuels shows the following: when gasifying, the amount of ash decreases from 15-20\% (at direct burning) to $7 \%$ [8] and the amount of $\mathrm{SO}_{2}$ and $\mathrm{NO}_{\mathrm{x}}$ emissions is 20-25\% lower [8]. Due to the high temperature in the active zone of the gasifier (over $1000{ }^{\circ} \mathrm{C}$ ), dangerous substances such as dioxins and furans are destroyed [9]. Total thermal efficiency of the straw gasification process reaches 78-85\% [10].

But gasifying like every other method of thermo-chemical conversion of low quality fuels is connected with difficulties. Volatile ash, which forms when gasifying this fuel, causes intense wear of metal surfaces of the gasifier parts. This wear is a result of corrosion influence of combustion products on metallic surfaces and deposits, rich in potassium chloride and potassium sulphates, formed on them 
[11]. It depends on the fuel chemical composition nuances, type of gasification process, technological parameters of the process, gasifier design features etc. [11;12]. Analysis of known scientific papers shows that there are a lot of works, which describe corrosion processes in boilers when burning different types of biomass [12;13]. However, special investigations of corrosion processes and material corrosion resistance in the gasifier during gasificatin of straw, lignin and their mixtures have not been done.

The aim of this work is to determine the influence of acidity and moisture content of a fuel mixture of chopped straw and hydrolyzed lignin and active zone temperature on the corrosion rate for different types of materials.

\section{Materials and methods}

To do the experiments a special gasifier was developed, Fig. 1, with downdraft gasifier with productivity $60-68 \mathrm{~m}^{3} \cdot \mathrm{h}^{-1}[14]$. The experiments were made at atmospheric pressure.
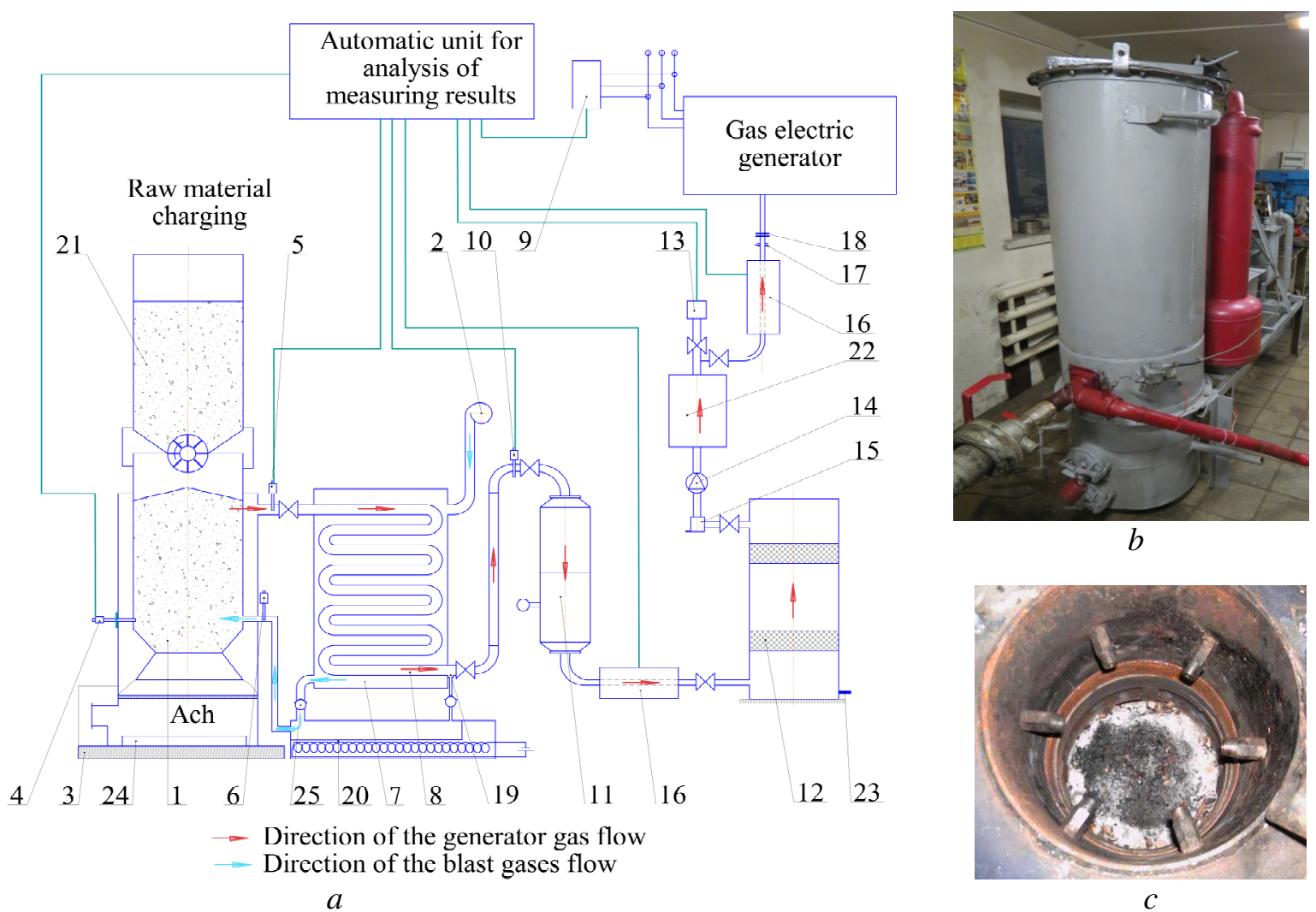

Fig. 1. Experimental gasifier unit: $a$ - schematic diagram; $b$ - general view; $c$ - gasifier chamber: 1 - downdraft gasifier; 2 - fan for air supply; 3 - laboratory scales TVE 500-10; 4 - tungsten-rhenium thermocouple TVR-251; 5, 6, 10 - chromel-alumel thermocouple TKhA-1172P; 7 - air-gas recuperator; 8 - gas pipe; 9 - electricity counter; 11 - cyclone; 12 - fine purification unit; 13 - CM6G calorimeter; 14 - vacuum pump; 15 - moisture separator; 16 - unit for gas sampling; 17 - throttle

washer; 18 - valve for the pipeline shut-off; 19 - pipe for condensate removing; 20 - evaporator; 21 - raw material bin; 22 - receiver; 23 - condensate drainage pipe; 24 - scales for ash weighing TVE $150-5 ; 25$ - return valve

A mixture of hydrolyzed lignin and chopped wheat straw was used as a fuel for the gasifier. Content of the main components in hydrolyzed lignin in \% of dry mass was: $12.6-31.9 \%$ polysaccharides, 48.3-72.0 \% lignin; acidity in recount on $\mathrm{H}_{2} \mathrm{SO}_{4}-\mathrm{pH} 2-2.5$, ash 0.7-9.6\%.

Chopped wheat straw was added in form of polyfractional composition with mean stem length $25 \mathrm{~mm}$. Straw composition in dry mass, main components: $N=0.52 \%, C=44.43 \%, H=5.86 \%$, $O=44.43 \%, S=0.11 \%$, ash $-6.5 \%$.

Depending on the quantity of chopped straw and hydrolyzed lignin three variations of mixture were prepared: mixture No. 1 - 50\% chopped straw and 50\% hydrolyzed lignin; mixture No. 2 - 
$60 \%$ chopped straw and $40 \%$ hydrolyzed lignin; mixture No. $3-70 \%$ chopped straw and $30 \%$ hydrolyzed lignin. Mixtures were poured in three different tanks. Acidity of the fuel mixture No. 1 was pH5, mixture No. 2 - pH5.5, mixture No. 3 - pH6.

A task was to determine the metal specimen corrosion rate $V$ by making a multifactor experiment when gasifying fuel mixtures No. 1, No. 2 and No. 3.

At first three identical specimens of $15 \mathrm{Cr} 21 \mathrm{~N} 5 \mathrm{~T}$ in form of square plates $25 \times 25 \mathrm{~mm}$ were hanged in the upper cone of the gasification chamber with alundum rings. The maximal concentration of hydrogen sulphide is observed in this part of the chamber. Than the fuel mixture No. 1 was loaded in the gasifier and the process of gasification started. During operation, according to the consequence defined by the plan of the experiment, the fuel moisture content can be varied, then the active zone temperature can be varied and the corrosion rate of the metal plate measured. After the end of the experiment one fuel mixture with different acidity was loaded (mixture No. 2, than mixture No. 3) and the experiment was repeated. Temperature in the active zone of the gasification chamber was between $600-1000{ }^{\circ} \mathrm{C}$. Gas temperature at the burner intake was $38-40{ }^{\circ} \mathrm{C}$. Each experiment duration was 24 hours, then the air supply stopped that stopped the gasification process. Then the gasifier was cooled down for 6 hours and afterwards the specimens were changed. A similar experiment was made for specimens made of S32109, A57036 and Ni70Cr27Al.

Factor variation intervals are: acidity of the fuel mixture $\mathrm{pH}$ 5, 5.5 and 6; moisture content of the fuel mixture $W^{P}-25,35$ and $45 \%$; temperature in the active zone of the gasification chamber $T-600$, $800,1000^{\circ} \mathrm{C}$. Factors encoding: $\mathrm{pH}=X_{1}, W^{P}=X_{2}, T=X_{3}$.

Variation levels of the abovementioned factors are given in Table 1.

Table 1

Variable factors and limits of their variation for definition of material corrosion rate

\begin{tabular}{|c|c|c|c|}
\hline $\begin{array}{c}\text { Factor variation } \\
\text { level }\end{array}$ & $\begin{array}{c}\text { Acidity of fuel } \\
\text { mixture, } \mathbf{p H}\end{array}$ & $\begin{array}{c}\text { Moisture content of } \\
\text { fuel mixture } \boldsymbol{W}^{\boldsymbol{P}}, \boldsymbol{\%}\end{array}$ & $\begin{array}{c}\text { Temperature in active zone of } \\
\text { gasification chamber } \boldsymbol{T},{ }^{\mathbf{0}} \mathbf{C} \text {. }\end{array}$ \\
\hline Upper level (+) & 6 & 45 & 1000 \\
\hline Middle level (0) & 5.5 & 35 & 800 \\
\hline Lower level (-) & 5 & 25 & 600 \\
\hline
\end{tabular}

To reduce the number of experiments and obtain the regression equation, the mathematical method of the experiment planning based on the Box-Behnken quadric plan was used [15].

Planning stage included the following steps: factor encoding, scheduling, randomization tests, implementation plan of the experiment, testing of reproducibility of the experiments, calculation of regression coefficients, assessment of significance of regression coefficients and adequacy of the test model [15]. For experimental data certainty repetition of experiments under the same conditions equals $k=3$. Eight original experiments were made according to the planning matrix and polynomial linear part coefficients were calculated according to [15]. The values of the model's relative error for all experiments according the plan of multifactor analysis are lower than $3 \%$ [14]. The values of mean relative deviation are lower than $1.87 \%$ [15]. As it can be seen, the relative error values less than $10 \%$ are considered acceptable in modelling of the corrosion process [15]. Therefore, it can be concluded that the presented model predicts the material corrosion process with a high accuracy.

\section{Results and discussion}

As a result of the laboratory experiments and statistical computation a data array of the material corrosion process rate (15Cr21N5T) was received, see Table 2.

The experiment results were processed using the software "Statistica". Homogeneity of variances was tested by the Cochrane criterion. Since $G^{\text {com }}=0.16<G^{\text {tabl }}(0.05 ; 15 ; 2)=0.334$, the process is reproduced. When determining the confidence intervals for regression coefficients, the Student test was used, the tabulated value of which at a $5 \%$ level of significance and the number of degrees of freedom of experiment variance reproducibility $f_{1}=2$ was $t=4.3$ [15]. The significance of regression coefficients was tested according to the established confidence intervals and covariance. Adequacy test of the hypotheses of the obtained regression equation was performed by the Fisher criterion. The 
estimated value of this criterion in the dispersion of inadequacy $S_{\text {inadeq }}^{2}=0.242$ and dispersion $S_{y}^{2}=0.08$ reproducibility of the experiment was: $F^{c o m}=3.02$.

Table 2

Planning matrix of multifactor experiment

\begin{tabular}{|c|c|c|c|c|c|c|c|c|c|c|}
\hline \multirow{2}{*}{ № } & \multicolumn{3}{|c|}{$\begin{array}{c}\text { Experiment planning } \\
\text { method }\end{array}$} & \multicolumn{4}{|c|}{ Experiments results } & \multicolumn{3}{c|}{ Model adequacy check } \\
\cline { 2 - 12 } & $X_{1}$ & $X_{2}$ & $X_{3}$ & $V_{\text {cor } 1}$ & $V_{\text {cor } 2}$ & $V_{\text {cor } 3}$ & $V_{\text {med }}$ & $V_{\text {med.com }}$ & $\begin{array}{c}\left(V_{\text {med }}-\right. \\
\left.V_{\text {med.com }}\right)\end{array}$ & $\begin{array}{c}\left(V_{\text {med }}-\right. \\
\left.V_{\text {med.com }}\right)^{2}\end{array}$ \\
\hline 1 & + & + & 0 & 22.62 & 22.42 & 23.06 & 22.7 & 23.29 & -0.59 & 0.35 \\
\hline 2 & + & - & 0 & 20.37 & 20.16 & 20.37 & 20.3 & 20.46 & -0.15 & 0.02 \\
\hline 3 & - & + & 0 & 30.84 & 30.86 & 30.7 & 30.8 & 30.65 & 0.16 & 0.02 \\
\hline 4 & - & - & 0 & 23.87 & 24.05 & 24.08 & 24.0 & 23.41 & 0.59 & 0.35 \\
\hline 5 & 0 & 0 & 0 & 24.12 & 24.04 & 24.14 & 24.1 & 24.26 & -0.16 & 0.03 \\
\hline 6 & + & 0 & + & 23.96 & 23.67 & 24.07 & 23.9 & 24.07 & -0.17 & 0.03 \\
\hline 7 & + & 0 & - & 21.06 & 21.15 & 20.79 & 21.0 & 20.17 & 0.83 & 0.68 \\
\hline 8 & - & 0 & + & 27.17 & 27.22 & 27.21 & 27.2 & 28.03 & -0.83 & 0.68 \\
\hline 9 & - & 0 & - & 26.74 & 26.62 & 26.74 & 26.7 & 26.53 & 0.17 & 0.03 \\
\hline 10 & 0 & 0 & 0 & 24.38 & 24.72 & 24.65 & 24.58 & 24.26 & 0.32 & 0.1 \\
\hline 11 & 0 & + & + & 31.8 & 31.86 & 31.44 & 31.7 & 30.97 & 0.73 & 0.53 \\
\hline 12 & 0 & + & - & 25.81 & 25.71 & 25.58 & 25.7 & 25.97 & -0.27 & 0.07 \\
\hline 13 & 0 & - & + & 23.77 & 23.9 & 24.03 & 23.9 & 23.63 & 0.27 & 0.07 \\
\hline 14 & 0 & - & - & 22.37 & 22.59 & 22.54 & 22.5 & 23.23 & -0.73 & 0.53 \\
\hline 15 & 0 & 0 & 0 & 23.96 & 24.35 & 23.99 & 24.1 & 24.26 & -0.16 & 0.03 \\
\hline
\end{tabular}

Regression coefficients: $b_{0}=36.51 ; b_{1}=2.54 ; b_{2}=0.5 ; b_{3}=-0.05 ; b_{12}=-0.22 ; b_{13}=0.0006$; $b_{11}=0.0072 ; b_{33}=0.24 \cdot 10^{-4}$.

After calculating the coefficients of the regression equation, their significance was estimated. The coefficients $b_{23}$ and $b_{22}$ appeared less than the confidence interval and hence were considered statically insignificant and were excluded from the regression equation.

After elimination of the abovementioned coefficients, the polynomial equation got the form:

$$
\begin{aligned}
& V_{\text {cor }}=36.51+2.54 \cdot p H+0.5 \cdot W^{p}-0.05 \cdot T-0.22 \cdot p H \cdot W^{P}+ \\
& +0.6 \cdot 10^{-3} \cdot T \cdot W^{P}+0.0072 \cdot\left(W^{p}\right)^{2}+0.24 \cdot 10^{-4} \cdot T^{2},
\end{aligned}
$$

where $V_{\text {cor }}-$ speed of the material corrosion process, $\mathrm{mg} \cdot(24 \text { hour })^{-1}$;

$\mathrm{pH}$ - acidity of the fuel mixture;

$W^{P}$ - moisture content of the fuel mixture, $\%$;

$T$ - temperature in the active zone of the gasification chamber, ${ }^{\circ} \mathrm{C}$.

Tabular value of the Fisher's exact test adopted by the $5 \%$ of significance, according to [15], was: $F^{t a b l}\left(0.05 ; f_{1} ; f_{2}\right)=19.38$, where $f_{2}=8$ variance inadequacy degrees of freedom $f_{1}=2$ - variance experiment reproducibility degrees of freedom. Since, $F^{\text {com }}=3.02<F^{\text {tabl }}\left(0.05 ; f_{1} ; f_{2}\right)=19.38$, the hypothesis by the adequacy of the regression equation is confirmed.

The coefficient of determination $R^{2}=0.96$.

Graphical representations of the abovementioned equation are given in Fig. 2-4.

The conditions: gasification chamber temperature, composition and moisture content of a fuel mixture of chopped straw and hydrolyzed lignin, at which the corrosion rate is minimal was defined experimentally. When changing acidity of the fuel mixture from $\mathrm{pH} 5$ to $\mathrm{pH} 6$ the corrosion rate $V_{c o r}$ of a specimen made of $15 \mathrm{Cr} 21$ N5T lowers. This tendency could be seen on all graphical representations Fig. 2-4.

Raising temperature $T$ in the gasification chamber active zone and usage of a fuel mixture with higher moisture content $W^{P}$ promotes speeding up the corrosion processes. Lowest corrosion rate $V_{\text {cor }}=19.5 \mathrm{mg} \cdot(24-\mathrm{h})^{-1}$ was observed at $\mathrm{pH} 6$, fuel mixture moisture content $W^{P}=25 \%$ and the gasification chamber active zone temperature $T=600{ }^{\circ} \mathrm{C}$. However, when the gasification chamber 
temperature is $T=600{ }^{\circ} \mathrm{C}$, the gasification process runs droopingly. When gasifying a fuel mixture with the moisture content $W^{P}=25 \%$, a low quality generator gas was received with higher calorific value of $Q_{H C V}=4.8 \mathrm{MJ} \cdot \mathrm{Nm}^{-3}$ and dry gas output of $v_{c}=1.6 \mathrm{~m}^{3} \cdot \mathrm{kg}^{-1}$. When gasifying a fuel mixture with the moisture content $W^{P}=45 \%$ at $T=600^{\circ} \mathrm{C}$, the received generator gas had higher calorific value of $Q_{H C V}=3.3 \mathrm{MJ} \cdot \mathrm{Nm}^{-3}$ and the output of dry gas was $v_{c}=1.4 \mathrm{~m}^{3} \cdot \mathrm{kg}^{-1}$. The fuel layer resistance rose from $8 \mathrm{~Pa}$ to $27 \mathrm{~Pa}$ because of intense slagging rate of $1.2 \mathrm{~kg} \cdot \mathrm{h}^{-1}$. Thermal productivity of a gasifier declined at the end of eight hours of operation from $645 \mathrm{MJ} \cdot \mathrm{h}^{-1}$ to $168 \mathrm{MJ} \cdot \mathrm{h}^{-1}$. Thermal productivity stability was violated. The received producer gas contained a significant amount of tars more than $120 \mathrm{~g} \cdot \mathrm{Nm}^{-3}$ and mechanical impurities $-98 \mathrm{~g} \cdot \mathrm{Nm}^{-3}$. In [16] similar results were achieved: when gasifying chopped straw with the moisture content over $40 \%$, the slagging rate was $1.24 \mathrm{~kg} \cdot \mathrm{h}^{-1}$.

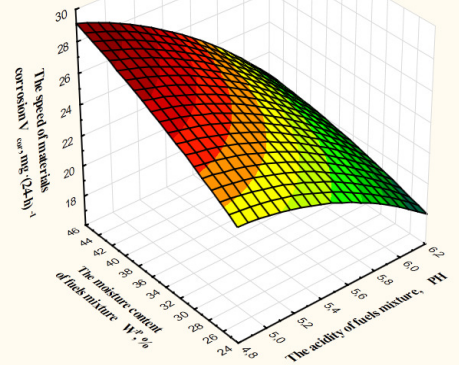

$a$

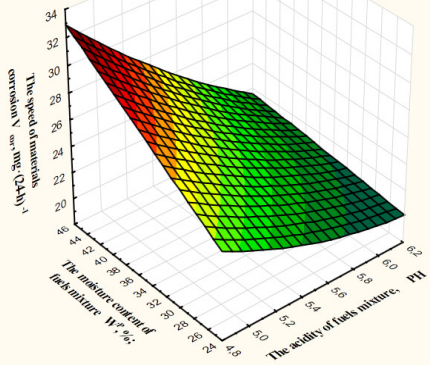

$b$

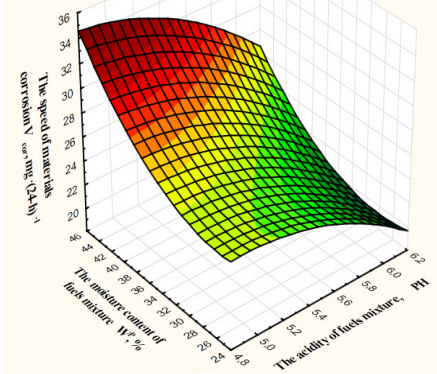

C

Fig. 2. Material corrosion rate $V_{\text {cor }}$ against mixture moisture content $W^{P}$ and mixture acidity pH: $a-\mathrm{T}=600{ }^{\circ} \mathrm{C} ; b-\mathrm{T}=800^{\circ} \mathrm{C} ; c-\mathrm{T}=1000^{\circ} \mathrm{C}$

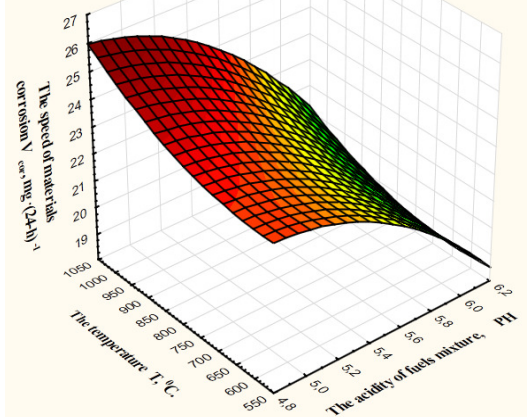

$a$

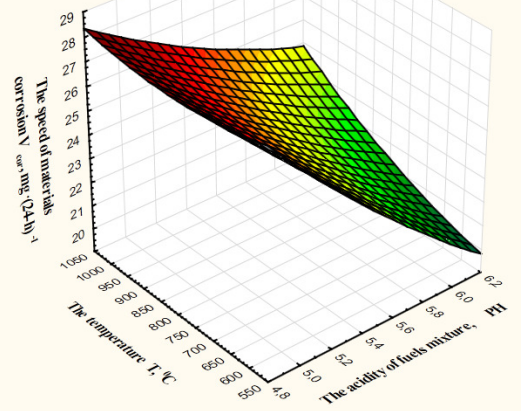

$b$

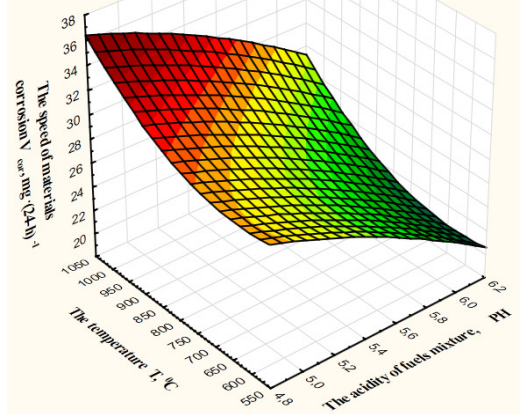

$c$

Fig. 3. Material corrosion rate $V_{\text {cor }}$ against mixture acidity $\mathrm{pH}$ and temperature in active zone of gasifying chamber $T: a-W^{P}=25 \% ; b-W^{P}=35 \% ; c-W^{P}=45 \%$

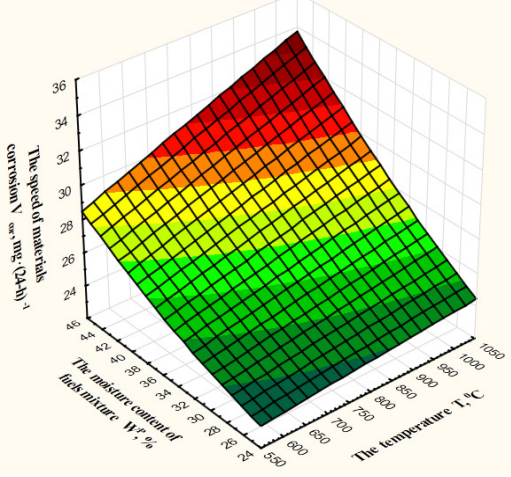

$a$

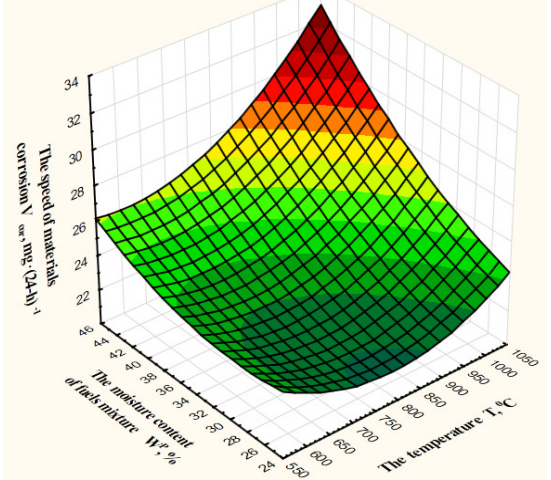

$b$

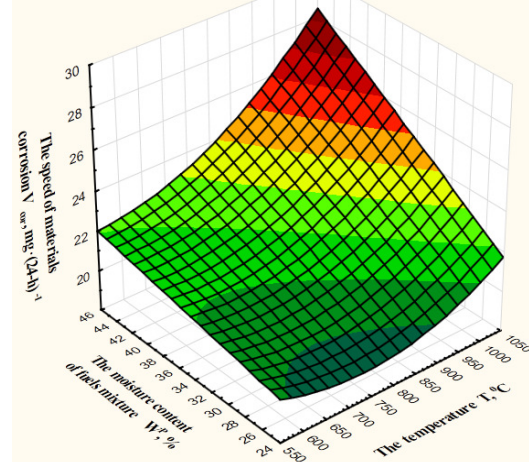

$c$

Fig. 4. Material corrosion rate $V_{c o r}$ against mixture moisture content $W^{P}$ and temperature in active zone of gasifying chamber $T: a-\mathrm{pH} 5 ; b-\mathrm{pH} 5.5 ; c-\mathrm{pH} 6$ 
Raising the temperature in the gasification chamber active zone from 600 to $1000{ }^{\circ} \mathrm{C}$, the corrosion rate rose by $8 \%$ for the mixture with acidity pH6 and moisture content $25 \%$ and by $17 \%$ for the mixture with acidity $\mathrm{pH} 5$ and moisture content $45 \%$. Raising the gasification chamber active zone temperature to $T=1000{ }^{\circ} \mathrm{C}$ and lowering the fuel mixture moisture content with acidity $\mathrm{pH}$ to $W^{P}=25 \%$, the highest quality producer gas was received with the calorific value $Q_{H C V}=9.6 \mathrm{MJ} \cdot \mathrm{Nm}^{-3}$, and $v_{c}=2.7 \mathrm{~m}^{3} \cdot \mathrm{kg}^{-1}$ (according to [4] in the gasifyer with a solid layer gasifying wood the calorific value of the received gas was $Q_{H C V}=10.4 \mathrm{MJ} \cdot \mathrm{Nm}^{-3}$ ). Meanwhile, the corrosion rate was $V_{c o r}=21.15 \mathrm{mg} \cdot(24 \text { hour })^{-1}$, that is significantly higher than the minimal rate $V_{\text {cor }}=19.5 \mathrm{mg} \cdot(24 \text { hour })^{-1}$. This proves that temperature in the gasification chamber $T$ influences the corrosion processes $\left(V_{\text {cor }}\right)$ less than the moisture content $W^{P}$ and acidity $\mathrm{pH}$ of the fuel. The highest corrosion rate $\left(V_{\text {cor }}=33.2 \mathrm{mg} \cdot(24 \text { hour })^{-1}\right)$ was observed for $T=1000{ }^{\circ} \mathrm{C}, W^{P}=45 \%$ and fuel mixture acidity $\mathrm{pH} 5$.

Thus, to provide the gasification process stability and receive a high quality producer gas $\left(Q_{H C V}=9.6 \mathrm{MJ} \cdot \mathrm{Nm}^{-3}\right.$ and up $)$ gasifiyng a mixture of hydrolyzed lignin and chopped straw $-70 \%$ of the mixture by mass should be chopped straw and $30 \%$ lignin. Such composition of fuel mixture makes its acidity equal to around $\mathrm{pH} 6$.

It is found that exactly the inorganic constituents, such as $\mathrm{K}, \mathrm{Na}, \mathrm{S}, \mathrm{Cl}, \mathrm{P}, \mathrm{Ca}, \mathrm{Mg}, \mathrm{Fe}, \mathrm{Si}$, are causing fouling, slagging and toxic emissions. When gasifying mixtures No. 1, No. 2 and No. 3, chloride and sulphide corrosion was developing. Chemical analysis of sinter layers from the surface of the specimen made of $15 \mathrm{Cr} 21 \mathrm{~N} 5 \mathrm{~T}$ gasifying mixture No. 3 shows that the chlorine content in sinter layers was significantly higher than the mean concentration of chlorine in volatile ash from the gasifier. Content of chlorine in sinter layers gasifying mixture No. 3 was more than 8 times higher of that for the mixture No. 1. Concentration of sulphur was the same as in ash, concentration of sodium and potassium was significantly lower.

The X-ray spectral analysis of specimens made of $15 \mathrm{Cr} 21 \mathrm{~N} 5 \mathrm{~T}$ shows that enrichment with chlorine mostly takes place on the metal-sinter division surface. Corrosion is explained by creation of a significant amount of alkali metal chlorides under conditions of high temperature during gasification. They precipitate on the metal surface and react with interjacent (transitive) gases, which excrete from reaction zones of the gasification chamber. Than sulphides are created and loose chlorine excretes. Part of loose chlorine then diffuses multiple times through pores of the sinter towards the surface of metal and reacts creating $\mathrm{FeCl}_{3}$ and $\mathrm{FeCl}_{2}$. When $\mathrm{FeCl}_{3}$ and $\mathrm{FeCl}_{2}$ react with oxygen $\mathrm{Fe}_{2} \mathrm{O}_{3}$ and $\mathrm{Fe}_{3} \mathrm{O}_{4}$ are created. Hence, chlorine acts as a corrosion catalyst. Thick and porous layers of sinter do not protect material of the specimen (15Cr21N5T), therefore its further ruination is observed.

It must be admitted that besides corrosion ruination of specimen there also deposits of $\mathrm{Ca}_{3} \mathrm{SiO}$, $\mathrm{KAl}_{3} \mathrm{SiO}$ were formed, which are very hard to remove. Similar investigations burning wood residues with adding of other types of biomass in an industrial Woodland boiler were described in [12]. In that paper a composition of deposits was defined with the help of the $\gamma$-spectrometry method $\mathrm{CaMg}\left(\mathrm{SiO}_{3}\right)_{2}, \mathrm{CaSiO}_{3}, \mathrm{KAlSiO}_{3} \mathrm{O}_{8}$.

Similarly to the experiments with plates made of $15 \mathrm{Cr} 21 \mathrm{~N} 5 \mathrm{~T}$ experiments with plates made of S32109, A57036 and Ni70Cr27Al were done.

The results are presented in Table 3.

Table 3

Results of corrosion tests when gasifying fuel mixture No. 3

\begin{tabular}{|c|c|c|c|c|c|c|c|c|c|c|}
\hline \multirow{2}{*}{$\begin{array}{c}\text { Temperature } \\
\mathbf{}^{\mathbf{0}} \mathbf{C}\end{array}$} & \multicolumn{4}{|c|}{ S32109 } & \multicolumn{3}{c|}{ Ni70Cr27Al } & \multicolumn{3}{c|}{ A57036 } \\
\cline { 2 - 10 } & $25 \%$ & $35 \%$ & $45 \%$ & $25 \%$ & $35 \%$ & $45 \%$ & $25 \%$ & $35 \%$ & $45 \%$ \\
\hline 600 & 19.72 & 21.96 & 23.07 & 24.29 & 27.26 & 28.72 & 69.16 & 88.34 & 104.26 \\
\hline 800 & 20.05 & 22.98 & 23.48 & 25,87 & 30.64 & 32.02 & 79.11 & 103.92 & 122.87 \\
\hline 1000 & 20.74 & 23.79 & 24.32 & 28,38 & 32.18 & 34.48 & 84.67 & 114.71 & 135.08 \\
\hline
\end{tabular}

The run of high temperature chloride and sulphide corrosion showed such tendency. A blackbrown sinter, 0.3-0.4 mm thick, appeared on the surface of the specimen made of A57036. Almost all specimens showed sinter cracking and exfoliation, hence it was thoroughly removed from the surface 
before weighing. Also there were some tar deposits on the specimen surface, which were easily removed with solvents. When the temperature is lower than $300-400{ }^{\circ} \mathrm{C}$, a film of $\mathrm{FeS}$, which is created on the metal surface, is more durable.

Alloyed steels showed more resistance against the influence of high temperature chloride and sulphide corrosion. A thin layer of black coloured sinter formed on their surface. The sinter was dense and had strong adhesion to the metal surface. Only for plates made of S32109 oxidation film exfoliation was observed. A local corrosion on the surface was noticed. On the rest of the specimens corrosion was uniform.

Gasifying the mixture No. 1 a corrosion rate was somewhat higher. It is explained by higher temperature in the reaction zone and also by the fact that it was a mixture of hydrolyzed lignin and chopped straw with 1:1 ratio. Some difference, however, was observed for corrosion of S32109. A slight exfoliation of oxidation film was observed as well, but significant difference was that there was no local corrosion noticed. So, high temperature chloride and sulphide corrosion runs differently for different metals and alloys. Between temperatures $900-1000{ }^{\circ} \mathrm{C}$ it is significantly intense. Raising the nickel content in alloys lowers its corrosion resistance for some alloys, which is seen from the experiments with Ni70Cr27Al.

Additionally, an investigation of gasification of fuel mixtures No. 1, No. 2 and No. 3 with the moisture content $W^{P}=25 \%$ with usage of steam-air blowing was made. The gasification chamber active zone temperature was $900-1000^{\circ} \mathrm{C}$. Adding of superheated steam for high temperature gasification stabilizes the gasification process and leads to significant reduction of ash-slag agglomeration, which is very distinctive for burning fuels containing straw [14]. Nonetheless, using air with superheated steam as blowing gases speeds up the corrosion processes several times.

The presented investigations could form a base for further investigations of corrosion processes, which take place in materials of thermotechnical equipment used to produce energy by thermochemical conversion of low quality biofuels.

\section{Conclusions}

The experimental study and numerical simulation of the corrosion process development rate in specimens made of metals have led to the following conclusions.

1. With help of the multifactor experiment with further data analysis it was found that the moisture content influences corrosion more than acidity. Minimal corrosion rate $19.5 \mathrm{mg} \cdot(24 \mathrm{hour})^{-1}$ for the specimen made of $15 \mathrm{Cr} 21 \mathrm{~N} 5 \mathrm{~T}$ was observed gasifying the fuel mixture $(70 \%$ chopped straw $30 \%$ hydrolyzed lignin) with the moisture content $25 \%$ and $\mathrm{pH} 6$.

2. Raising the temperature in the gasification chamber active zone from 600 to $1000{ }^{\circ} \mathrm{C}$, the corrosion rate rises by $8 \%$ for the mixture with the moisture content $25 \%$ and pH6 and by $17 \%$ for the mixture with the moisture content $45 \%$ and $\mathrm{pH} 5$. However, the gasification process must be run within the temperature range $900-1000{ }^{\circ} \mathrm{C}$, since only at such conditions the highest quality producer gas can be received with higher calorific value $9.6 \mathrm{MJ} \cdot \mathrm{Nm}^{-3}$ and output of $2.7 \mathrm{~m}^{3} \cdot \mathrm{kg}^{-1}$ for the fuel mixture with the moisture content $25 \%$ and acidity $\mathrm{pH} 6$.

3. It is set that gasifying mixtures of chopped straw and hydrolysed lignin with the temperature in the gasification chamber above $900{ }^{\circ} \mathrm{C}$ chloride and sulphide corrosion is developing on metallic plates made of $15 \mathrm{Cr} 21 \mathrm{~N} 5 \mathrm{~T}, \mathrm{~S} 32109$, A57036 and Ni70Cr27Al, which is caused by the action of alkali metal chlorides, and it is significantly high. Also deposits of $\mathrm{Ca}_{3} \mathrm{SiO}$ and $\mathrm{KAl}_{3} \mathrm{SiO}$ were formed, which are very hard to remove. On the specimens of S32109 besides uniform corrosion local corrosion was observed as well. Raising the nickel content in alloy is lowering its corrosion resistance for some alloys, which is confirmed with the specimen made of Ni70Cr27Al.

4. Adding superheated steam to blowing gases is intensifying all corrosion processes three times.

\section{References}

[1] Europe 2020 indicators - climate change and energy. Eurostat Statistics Explained, 2016. [online] [18.07.2018]. Available at: https://ec.europa.eu/eurostat/statisticsexplained/index.php/Europe_2020_indicators_-_climate_change_and_energy\#General_overview 
[2] Archive: Energy from renewable sources. Eurostat Statistics Explained, 2017. [online] [10.05.2017]. Available at: https://ec.europa.eu/eurostat/statistics-explained/index.php?title = Archive:Energy_from_renewable_sources\&oldid $=330126 \#$ Notes

[3] Вернера I.Є. Україна у цифрах 2017. Статистичний збірник (Ukraine in figures. Statistical collection). Kyiv: State Statistics Service of Ukraine, 2018. 241 p.

[4] Golub G., Kukharets S., Tsyvenkova N. etc. Experimental study into the influence of straw content in fuel on parameters of generator gas. Eastern-European Journal of Enterprise Technologies, vol. 5, No. 8, 2018, pp. 76-86. https://doi.org/10.15587/1729-4061.2018.142159

[5] Kakitis A., Nulle I., Ozollapins M. etc. Assessment of combustion parameters of biomass mixtures. Proceedings of International conference " Engineering for rural development 2015", May 20-22, 2015, Jelgava, Latvia, pp. 133-139. [online] [20.05.2015]. Available at: http://www.tf.llu.lv/conference/proceedings2015/Papers/022_Kakitis.pdf

[6] Karps O., Aboltins A., Palabinskis J. Biomass ash utilization opportunities in agriculture. Proceedings of the 8-th International Scientific Conference "Rural development 2017. Bioeconomy challenges", November 23-24, 2017, Aleksandras Stulginskis University, Lithuania, pp. 193-198. Available at: http://doi.org/10.15544/RD.2017.083

[7] Kumar V. Pyrolysis and Gasification of lignin and effect of alkali addition. Georgia: Georgia Institute of Technology, 2009. $178 \mathrm{p}$.

[8] Basu P. Biomass gasification, pyrolysis and torrefaction: practical design and theory. Elsevier, 2013. 548 p. Available at: https://doi.org/10.1016/c2011-0-07564-6

[9] Sheth P. N., Babu B. V. Experimental studies on producer gas generation from wood waste in a downdraft biomass gasifier. Bioresource Technology, vol. 1001, Issue 12, 2009, pp. 3127-3133. Available at: https://doi.org/10.1016/j.biortech.2009.01.024

[10] Barmina I., Valdmanis R., Zake M., etc. Development of gasification/combustion characteristics at thermo-chemical conversion of biomass mixtures. Proceedings of International conference "Engineering for rural development 2017", May 24-26, 2017, Jelgava, Latvia, pp. 54-59. [online] [24.05.2017]. Available at: http://tf.llu.lv/conference/proceedings2017/Papers/N011.pdf

[11] Melissari B. Ash related problems with high alkali biomass and its mitigation - Experimental evaluation. Engineering Research Report, No. 12, 2014, pp. 31-44.

[12] Baxter L.L., Miles T.R. Alkali diposits found in biomass boilers. Sandia National Laboratory, National Renewable Energy Laboratory, NREL/TR-433-8142 SAND 96-8225, Vol. 11, 1996.

[13] Frandsen R.B., Montgomery M., Larsen Ol. H. Field test corrosion experiences when co-firing straw and coal: 10 year status within Elsam. Materials at High Temperatures, 24(4), 2007, pp. 343-349. Available at: http://dx.doi.org/10.3184/096034007X278365

[14] Kukharets S., Tsyvenkova N., Yarosh Ya. etc. The results of study into the effect of air-steam blast on the low-grade fuel gasification process. Eastern-European Journal of Enterprise Technologies, vol. 6, No. 8(96), 2018, pp. 86-96.

[15] Мельников С.В., Ацелкин В.Р., Рощин П.М. Планирование эксперимента в исследованиях сельскохозяйственных процессов (An experiment planning in researches of agricultural processes). Leningrad: Kolos, 1980, 168 p. (In Russian).

[16]Мезин И.С. Транспортные газогенераторы (Automotive gas producers). Moskow: Ogiz Selhozgiz, 1948, 311 p. (In Russian). 